$3-2015$

\title{
Ethnic Matching in the U.S. Venture Capital Market
}

Ola Bengtsson

David H. Hsu

University of Pennsylvania

Follow this and additional works at: http://repository.upenn.edu/mgmt_papers

Part of the Business Administration, Management, and Operations Commons

\section{Recommended Citation}

Bengtsson, O., \& Hsu, D. H. (2015). Ethnic Matching in the U.S. Venture Capital Market. Journal of Business Venturing, 30 (2), 338-354. http://dx.doi.org/10.1016/j.jbusvent.2014.09.001 


\title{
Ethnic Matching in the U.S. Venture Capital Market
}

\begin{abstract}
We document the role of entrepreneurial founder and venture capital (VC) partner co-ethnicity in shaping investment relationships. Co-ethnicity increases the likelihood that a VC firm invests in a company.

Conditional on investment, co-ethnicity strengthens the degree of involvement by raising the likelihood of VC board of director involvement and increasing the size and scope of investment. These results are consistent with trust and social-network based mechanisms. Shared ethnicity in our sample is associated with worse investment outcomes as measured by investment liquidity, however, which our results suggest might stem from looser screening and/or corporate governance.
\end{abstract}

\section{Keywords}

venture capital, ethnic matching

\section{Disciplines}

Business Administration, Management, and Operations 


\title{
Ethnic Matching in the U.S. Venture Capital Market
}

\author{
Ola Bengtsson* and David H. Hsu**
}

First draft: January 2009. This draft: August 2012

\begin{abstract}
We document that ethnicity is a major determinant of how founders of U.S. startup companies match with partners of U.S. VC firms. A shared ethnicity increases the likelihood that a VC firm invests in a startup, strengthens the degree of the VC firm's involvement, increases the size and scope of the investment, and makes the financial contract more entrepreneur-friendly. These findings are robust to specifications with VC firm or startup company fixed effects. Based on our finding that a shared ethnicity is associated with worse investment outcomes (IPO or M\&A), we infer that a VC partner may overestimate the benefits of investing in a founder from the same ethnic group. Our paper adds new evidence on the role of ethnic minorities in entrepreneurship, and contributes to prior studies of how VC firms overcome informational frictions.
\end{abstract}

\footnotetext{
${ }^{*}$ Department of Economics, Lund University, and ** Wharton School, University of Pennsylvania. We appreciate the comments from Bill Kerr, Antoinette Schoar, Morten Sorensen, Ivo Welch, and seminar participants at the RFS/Kauffman Entrepreneurial Finance and Innovation Conference, the Academy of Management Annual Meeting, and UNC-Chapel Hill. We thank our institutions for funding this project, and Kyle Wang for excellent research assistance. Hsu acknowledges the additional financial support of the Alfred P. Sloan Foundation through an Industry Studies Fellowship. Contact information: Ola.Bengtsson@nek.lu.se; dhsu@wharton.upenn.edu.
} 


\title{
Ethnic Matching in the U.S. Venture Capital Market
}

\begin{abstract}
We document that ethnicity is a major determinant of how founders of U.S. startup companies match with partners of U.S. VC firms. A shared ethnicity increases the likelihood that a VC firm invests in a startup, strengthens the degree of the VC firm's involvement, increases the size and scope of the investment, and makes the financial contract more entrepreneur-friendly. These findings are robust to specifications with VC firm or startup company fixed effects. Based on our finding that a shared ethnicity is associated with worse investment outcomes (IPO or M\&A), we infer that a VC partner may overestimate the benefits of investing in a founder from the same ethnic group. Our paper adds new evidence on the role of ethnic minorities in entrepreneurship, and contributes to prior studies of how VC firms overcome informational frictions.
\end{abstract}




\section{Introduction}

Informational frictions impede the provision of external finance, particularly for companies with opaque, intangible assets. We study how partners at venture capital (VC) firms overcome such frictions by investing in startup founders with whom they share a common ethnicity. Analyzing a large dataset covering a broad cross-section of the U.S. VC industry, we find that a shared ethnicity is associated with a higher probability that the $\mathrm{VC}$ firm invests in the startup, stronger $\mathrm{VC}$ firm involvement conditional on such an investment taking place, and more entrepreneur-friendly financial contracts. These results are economically significant and are robust to a variety of controls, including VC firm and startup fixed effects. However, we also show that a shared ethnicity is associated with a lower probability of successful exit. Our findings suggest that a shared ethnicity mitigates search, selection and monitoring costs, but VC firms appear to overestimate such benefits and either match with startups of inferior quality or do not impose a sufficient level of control on their portfolio companies.

By presenting detailed evidence on the importance of shared ethnicity in the U.S. VC market, we make two key contributions. Our first contribution is to validate the role of ethnic minorities in entrepreneurship by documenting the role ethnicity plays in the provision of venture finance. Research by Saxenian and coauthors suggests that entrepreneurs who are immigrants and/or belong to an ethnic minority form a large subgroup of all innovation-based startup founders in the United States (Saxenian 1999, 2006; Wadhwa et al. 2007). For startups launched between 1995 and 2005, there was at least one immigrant key founder in $25 \%$ of technology and engineering companies across the U.S., and in $52 \%$ of all companies based in Silicon Valley. A sizeable fraction of VC firms also employ professionals who come from an ethnic minority: Our data reveal that $14 \%$ of all VC firms have at least one partner who is either Chinese or Indian. Individuals with a shared ethnicity often form networks where they interact and exchange ideas with each other. As reported by Saxenian (2006), there are at least 30 professional and networking associations targeting immigrants in Silicon Valley (e.g., The Indus Entrepreneur, TiE) composing over 33,000 members. 
Collectively, these statistics suggest that ethnicity could be important for how the U.S. VC market operates. We formally test this expectation, and show that a shared ethnicity (between partners and founders) matters for whether, when and how VC firms invest in startups. Our evidence adds broadly to the growing literature that shows that social proximity, in addition to geographical proximity, can matter for finance (Cohen et al., 2008). We also add to the literature that shows the importance of ethnicity for trust (Glaeser, 2000; Fisman, 2003), innovation (Agrawal et al., 2007; Kerr, 2008) and founding team composition (Ruef et al., 2003).

Our second contribution is to shed new light on how VC firms overcome the severe informational frictions they encounter when financing startups. Existing research has uncovered several methods that VCs use to improve their information collection before and after the investment is made: They specialize in industries, geographies and investment stages (Stuart \& Sorenson, 2001; Chen et al., 2010) write sophisticated financial contracts (Kaplan \& Stromberg, 2003, 2004; Bengtsson \& Sensoy, 2011), experiment with new investment types (Sorensen, 2008), are actively involved in their portfolio companies (Lerner, 1995; Hellmann \& Puri, 2002), and syndicate deals with other trusted VCs (Lerner, 1994; Hochberg et al., 2007, 2010). Common to these solutions is that they derive from VC firm's capabilities, rather than from the quality of the personal match between the VC firm's partners and the startup's founders.

The quality of the personal match is arguably important in the VC market. In contrast to the typical financings utilized by mature companies (i.e., public equity, bonds, and bank loans), people shape the demand and supply of venture capital financing to a significant degree. On the demand side, the individual founder's human capital is a key asset in a young, entrepreneurial company. On the supply side, the VC firm consists of individual partners who screen, monitor and provide operational support to portfolio companies. Thus, the success of a startup hinges critically on the capabilities of its founders and partners (Hsu, 2007; Sorensen, 2007). Moreover, the relational nature of the VC market means that these two groups have frequent personal interactions with each other. Founders meet with partners during pitching, due diligence, contract negotiations, and board meetings. A high-quality match can arguably 
improve the startup's success chances, whereas a low-quality match can create tensions that impede value-creation.

In this paper, we focus our attention on one dimension of person-based matching — ethnicitybecause it can be measured reliably and comprehensively, and, as we discussed above, matters in practice. Our findings that $\mathrm{VC}$ firms use ethnicity as a criterion for how they select, monitor and contract with entrepreneurs confirm anecdotal evidence that social networks and trusted referrals are important in explaining the matching process on the VC market (Fried \& Hisrich, 1994). From a broader perspective, the findings add to the literature on the impact of culture in economic exchange (Becker, 1996; Guiso et al. 2006; Iyer \& Schoar, 2010), which defines culture as a set of shared values, beliefs, and norms of a group or community (a definition that fits well with ethnic minorities).

We analyze a dataset from the U.S. VC market, which is collected from VentureEconomics. The final sample includes 9,079 unique VC firm-startup pairs. Importantly, the dataset covers both pairs for which the VC firm took a board seat and pairs for which it did not. We can thereby separately study whether the VC firm invested and whether it took a board seat, conditional on an investment. Our data are limited to investments for which VentureEconomics report the name of at least one VC firm partner and at least one startup founder. This restriction follows from our strategy of using names to infer the ethnicity of each individual. We focus on eight ethnicities: Jewish, Indian (i.e., from India), Chinese, Korean, Hispanic, Russian, Japanese and Vietnamese. These ethnicities are chosen because they can be identified using our data on names, and they represent important minority ethnicities in the U.S. Hence, we deliberately do not analyze ethnic groups that frequently share names with other ethnicities. For example, Danish and Norwegian names are often similar. We also do not analyze "broad" ethnic groups, such as Anglo-Saxon/British, because they consist primarily of individuals with little or no connection to each other due to shared ethnicity.

Our empirical methodology is straightforward, yet it permits us to assess the importance of shared ethnicity. We run a series of regressions with "Same Ethnicity" as the focal independent variable (which is a dummy that takes the value 1 if partner and founder have the same ethnicity, and is 0 otherwise). All 
specifications include fixed effects for company industry, location, and year of investment. We also run separate robustness regressions with company fixed effects and VC firm fixed effects, respectively. Because the coefficient on "Same Ethnicity" remains qualitatively similar across specifications with different included fixed effects, we infer that our results are likely not driven by omitted variables. Including company and $\mathrm{VC}$ firm fixed effects also broadens the interpretation of our findings. Our regressions with company fixed effects compares the investment behaviors of the focal VC firm versus other VC firms investing in the focal company; our regressions with VC firm fixed effects compares the focal VC firm's investment behavior in the focal company versus in other companies.

We document five results on matching based on ethnicity. First, a shared ethnicity is associated with a higher probability that the $\mathrm{VC}$ firm invests in the startup. We derive this result by comparing the instance of shared ethnicity between actual investments and counterfactual ones. Second, conditional on investment, we find that a shared ethnicity is associated with a higher probability that the VC firm takes a board seat. Third, a shared ethnicity is associated with the $\mathrm{VC}$ firm being more likely to invest at an early stage of the startup. Fourth, a shared ethnicity is associated with the VC firm investing more capital and across more rounds in the startup. Finally, we find that a shared ethnicity is associated with the VC firm offering higher pre-money valuation and receive fewer investor-friendly cash flow contingency rights in the financial contract.

These findings unambiguously show that a shared ethnicity predicts the existence and intensity of the match between the VC firm and the startup. Our next step is to investigate how such matching relates to investment outcomes. Either relationship is possible, because there are competing rationales for why personal-based matching happens in the $\mathrm{VC}$ market.

On the one hand, a VC firm could derive several benefits from making co-ethnic investments. Consider a U.S. startup firm founded by an Indian-born entrepreneur that seeks venture funding. An Indian-born (U.S.-based) partner may have soft information that allows him or her to better evaluate the ability and personality of this entrepreneur (Stein, 2002; Petersen \& Rajan, 2002; Petersen, 2004; Berger et al., 2005; Cohen et al., 2008). Moreover, the partner may be a member of the same ethnic-based 
network as the entrepreneur. Such a network can provide the partner with additional soft information and trust and reputation to his/her relationship with the entrepreneur (Greif, 1989, 1993; Landa 1994; Glaeser et al. 2000; Casella \& Rauch 2002; Fisman 2003). The partner and entrepreneur may also have more productive board meetings after the investment is made. This could improve the likelihood the firm will realize a successful exit, given that the board of a venture-backed firm engages in both monitoring and value-add support. If these benefits were important in practice, then we would expect to observe co-ethnic investments to be prevalent and associated with superior performance.

On the other hand, investments with a co-ethnic may instead be associated with worse outcomes. The Indian-born partner may also be overconfident in his/her ability to evaluate and monitor Indian-born entrepreneurs, thereby matching with startups of inferior quality. Moreover, the partner may feel social pressure from the ethnic-based network to support entrepreneurs from the ethnic network. Rather than improving the VC's monitoring ability, boards with co-ethnic members may hold meetings that are too undemanding and/or impose too few control mechanisms on the entrepreneur. Moreover, unfounded trust could result in less intensive due diligence of the entrepreneurial company.

An alternative mechanism that predicts bad outcomes is groupthink (Janis, 1982), which is more likely to hold the more similar are the members of a group. ${ }^{1}$ While the evidence on groupthink in the social psychology literature is mixed (eg., Tetlock et al. 1992; Esser, 1998), the possibility that entrepreneurial actions might go unchallenged as a result of personal similarity with the $\mathrm{VC}$ may dampen ultimate outcomes. From a resource perspective, redundant ties (as would apply in co-ethnic networks) are less likely to yield diverse, valuable information (Granovetter, 1973), which can also hinder economic outcomes. While Granovetter considers the context of the job market, the idea is that "weak" ties (or looser, more diverse networks) are more likely to contain varied and non-redundant information, with beneficial ultimate effects (thus, the strength of weak ties). For example, Huang, Jin \& Qian (forthcoming)

\footnotetext{
${ }^{1}$ Tetlock (1979: 1314) defines groupthink: "Groupthink occurs when independent critical analysis of the problem facing the group assumes second place to group members' motivation to maintain group solidarity and to avoid creating disunity by expressing unpopular doubts or opinions."
} 
find that entry by ethnically Chinese firms (from Singapore, Hong Kong and Taiwan) into China is no more successful with regard to profitability than non-ethnically Chinese firms.

Our analysis suggests that matches based on a shared ethnicity are associated with less successful company outcomes. We document a negative correlation between "Same Ethnicity" and the chance of Initial Public Offering or Merger/Acquisition. ${ }^{2}$ This result suggests that partners of VC firms either overestimate the benefits of ethnicity when they select portfolio companies or fail to impose a sufficient level of monitoring after the investment is made. An important caveat for this part of our analysis is that we equate the investment outcome with the startups' exit mode due to data limitations. This outcome variable is a coarse measure of how $\mathrm{VC}$ investments create or destroy value, though it is one that is common in the entrepreneurial finance literature.

To summarize our findings, we show that co-ethnicity is a strong rationale for how VC firms match with entrepreneurial companies. A shared ethnicity increases the likelihood of a match occurring, and strengthens the VC firm's involvement conditional on a match. However, this rationale for matching is associated with worse investment outcomes. These empirical patterns are qualitatively similar to those documented by Gompers et al. (2012), who study matches between VC firms formed in investment syndicates. Like us, they find that co-ethnicity (which they label matching based on "affinity-based characteristics") increases the likelihood of a match but decreases the chance of a successful company outcome. Combined, our findings and those of Gompers et al. (2012) suggests that participants in the venture capital market should be careful when forming matches based on a shared ethnicity.

The remainder of the paper is structured as follows. Section 2 introduces the data. Section 3 first presents results on matching, and then discusses and distinguishes between competing explanations for our results. Section 4 is a brief concluding discussion.

\footnotetext{
${ }^{2}$ In a related paper, Hegde and Tomlinson (2011) confirm our finding that shared ethnicity predicts matching in the VC industry, but find a positive association with company outcome. This discrepancy can be attributed to critical differences in sample design and empirical methodology. Unlike our paper, Hegde and Tomlinson (i) include both U.S. and foreign VC firms/startups, (ii) code more ethnic groups, including "broad" ones (e.g., Anglo-Saxon/British), (iii) combine founders and individuals who are hired on later, and (iv) restrict their sample to investments where the VC firm took a board seat.
} 


\section{Data}

Sample Design. We collect our data from VentureEconomics, which is one of the largest and most complete databases on VC investments. ${ }^{3}$ We restrict our attention to U.S. VC investments in order to eliminate the influence of any institutional differences that exists across countries. We use the part of the VentureEconomics data that includes information on the name of the individuals who are involved in VC investments. The database collects this name information from web pages, news reports, press releases and proprietary surveys. For each startup (where information is available), we first identify the name of all company founders. As reported in Panel A of Table 1, our final sample includes 5,093 unique individuals who have founded 3,125 unique startups. Untabulated analyses show that our sample is a broad cross-section of startup locations, industries, and company ages and development stages at the time of financing.

We then obtain information about all the VCs that invested in each startup in our sample. Our dataset covers 2,361 unique individuals working as partners in 966 unique VC firms. Importantly, we include both VC firms that took a board seat and VC firms that did not. Our final sample includes 9,079 unique company-VC firm pairs. Each pair is formed by collapsing information on all (listed) company founders and all (listed) active partners at the VC firm.

The inclusion of VC firms with and without a board seat allows us to study not only how an ethnic match relates to the VC firm's investment in the company, but also how it relates to the decision to give the VC firm a board seat, conditional on an investment. This significantly broadens the scope of our study, but, it introduces an empirical challenge: we cannot directly measure the ethnicity of partners in VC firms that did not take a board seat. VentureEconomics and similar databases do not list the names of the partners who were active at a given point in time in a given VC firm. We approximate the list of active partners by identifying all individual partners in the VC firm, who took a board seat in any sample company that the VC firm financed during the same time period that it financed the focal company.

\footnotetext{
${ }^{3}$ Kaplan et al. (2002) report that the investment coverage of VentureEconomics is about $85 \%$. The fact that many companies in VentureEconomics report no VC board seats, however, suggests that this part of the data has lower coverage. As reported by Kaplan \& Stromberg (2003), VCs almost always have some representation at the board of directors.
} 
To illustrate our methodology, suppose VC Alpha in 2005 invested both in Company Beta and Company Gamma. VC Alpha took a board seat in Company Beta but not in Company Gamma. Suppose Company Gamma has a Chinese founder. From our data on board seats, we can directly observe the ethnicity of the partner(s) at VC Alpha who took a board seat at Company Beta. Suppose one such partner was Chinese. Since the VC firm's two investments were made in the same year, we classify the investment by VC Alpha in Company Gamma as a same-ethnic (Chinese-Chinese) match.

Our methodology relies on the assumption that all of the VC firm's active partners were, at least to some degree, involved in each investment. Our conversations with partners at VC firms confirm that this assumption describes the real-world VC investment process. ${ }^{4}$ In a statistical sense, if the assumption were wrong we may derive biased results on the importance of ethnicity. However, the likely bias is such that we would be less likely to find significant results because we would estimate the influence of ethnic ties that do not exist in practice. To see this, suppose in the above example that the Chinese partner at VC Alpha had no involvement in the investment in Company Gamma. If ethnicity were important then we would not identify it for the VC Alpha-Company Gamma pair. As we outline in Section 3, even in the presence of such possible bias, we find strong and pervasive empirical patterns consistent with the importance of ethnic ties. We also run our tests using only the subsample for which we observe that the VC firm took a board seat in the company. Results are qualitatively very similar for the full sample and this subsample, suggesting that our assumption is a valid one.

Ethnicity. We use each individual's surname to determine his or her ethnicity. Our information on ethnic surnames comes from two sources. First, we use the database constructed by Kerr (2008), which lists the 100 most common surnames for Chinese, Indian, Japanese, Korean, Russian, Hispanic, and Vietnamese. ${ }^{5}$

\footnotetext{
${ }^{4} \mathrm{~A}$ typical $\mathrm{VC}$ firm assigns one or a few partners to each investment, who become formally responsible for screening, contract negotiations, monitoring, operational support, etc. All major decisions pertaining to whether, when and how to invest are approved at a partner-wide meeting at the VC firm.

${ }^{5}$ In an earlier version of this paper we coded the ethnicity of founders and partners using both Kerr's database and biographical information (available for a smaller sample). We found that the there was a very large overlap between these coding methods, confirming that the use of name data captures most individuals from the focal ethnic groups.
} 
Secondly, we use a list from Wikipedia on the most common Jewish surnames. ${ }^{6}$ We limit our attention to these eight ethnicities because (i) they represent important subgroups that are active in the U.S VC industry, and (ii) the large overlap in surnames makes it difficult identify other ethnicities (e.g., many common Norwegian surnames are also common Danish surnames).

We create the variable "Same Ethnicity", which is the focus of our study, by comparing the ethnicity of any of the company's founders to that of any of the VC firm's partners. The variable takes the value 1 if there was an ethnic match based on the eight ethnic groups we have coded (i.e., ChineseChinese), and 0 if either there was no ethnic match (i.e., Chinese-Indian) or if none of the individuals were from the coded ethnic groups (i.e., Other-Other). For pairs where there are multiple founders and/or multiple partners, it is possible that there is more than one ethnic tie. As reported in Panel B of table 1, about $5 \%$ of all pairs involve an ethnic match.

Summary Statistics. We collect a variety of company, VC and round characteristics for our sample of company-VC firm pairs. Panel B of table 1 reports summary statistics of the focal variables. We note that $60 \%$ of all investments in our sample involve the VC firm taking at least one board seat. We use "VC IPO Experience" as our main proxy for the reputation/skill of the VC firm. This control variable captures the fraction of the VC firm's all historical portfolio companies that had a successful IPO exit. The variable is continuously updated so that it accurately reflects the VC firm's reputation/skill at the time of its first investment in the company. In untabulated robustness tests, we replace it with other proxies for the VC firm's reputation/skill, such as VC firm age and number of historical companies. Results remain unchanged.

We use two measures of company maturity at the time of the VC firm's first investment in the company: "Company Age First Time VC Invested in Company (years)" and "VC Invested in First Round of Company $(1=$ Yes, $0=N o)$." The average company age was 3 years and $44 \%$ of investments included a first round investment.

\footnotetext{
${ }^{6}$ http://en.wikipedia.org/wiki/Category:Jewish_surnames
} 
We use two measures of the VC firm's investment scope: "Number of Rounds VC Invested in Company" and "Total Dollar Amount VC Invested in Company (in \$m)." The average number of rounds was 2.2 and the average investment amount, which is a summation over all rounds in which the VC firm invested, was \$9.1 million.

We use two variables that measure the degree of company-friendliness of the financial contract: "Pre-Money Valuation (in \$m)" and "Downside Protection Index (Bengtsson and Sensoy, 2011)". Each variable is calculated as the across-round average for each VC firm-company pair. The first variable is pre-money valuation, which determines how large equity stake the VC firm received in exchange for its investment. The average pre-money valuation was $\$ 58$ million, but it is only reported for about half of our observations. Because this variable is self-reported by companies and $\mathrm{VC}$ firms, the selection bias is likely such that this subsample include the more valuable companies from our full sample.

The second variable, Downside Protection Index, determines how much downside protection the VC received beyond what is implied by its equity stake. A high Downside Protection Index reflects a less company-friendly financial contract. Bengtsson and Sensoy (2011) present a detailed discussion of the meaning and importance of each of the six key cash flow contingencies that form the basis for the Downside Protection Index variable. This variable, which is collected from mandatory "Certificate of Incorporation" legal filings, is only reported for about a quarter of our sample. Bengtsson and Sensoy (2011) analyze how this sample is selected and conclude that it is representative with regard to company characteristics, except that it is reported more often for companies that raise greater amounts of VC financing.

Finally, we use two measures that capture a successful outcome for the company: "IPO Exit $(1=$ Yes, $0=N o)$ " and "IPO or M\&A Exit $(1=$ Yes, $0=N o)$." We limit the sample to investments made prior to 2003 to ensure that all sample companies have sufficient time to realize their exit. ${ }^{7} 16 \%$ of investments resulted in an IPO and 58\% in a Merger and Acquisition (M\&A). These statistics are somewhat higher than reported in other studies, reflecting the fact that both founders and partners are more likely to report

\footnotetext{
${ }^{7}$ Our data was collected in 2009, so this cutoff translates into a 7 year time period of realizing an exit.
} 
their involvement in a successful venture-backed company. This selective reporting is likely to bias our results against finding results on ethnic ties, because companies with higher ex-ante probability of success likely have access to a broader group of VC firms, including those without an ethnic match. Put differently, ethnic ties plausibly should matter more for firms with low ex-ante probability of success, which are less prevalent in our data, because ethnic ties can alleviate the greater informational frictions surrounding such firms (Akerlof, 1970).

\section{Empirical Results}

Initial Evidence. If ethnic ties were important for how matches are formed in the VC industry, we would expect to observe that they occur with an unusually high frequency. Table 2 presents results consistent with this expectation. In the first column, labeled "VC firms where (at least) one partner has ethnicity", we report the frequency of pairs with (at least) one ethnic partner. As for the most common ethnicities, we note that about 20\% VC firms have a Jewish partner, 14\% an Indian, and 6\% Chinese. In the second column, labeled "Companies where (at least) one founder has ethnicity", we report the frequency of pairs with (at least) one ethnic founder. We note that about $8 \%$ have a Jewish founder, $9 \%$ an Indian, and $6 \%$ a Chinese. These statistics show that ethnic founders play an important role in the U.S. entrepreneurship landscape, a finding that has been highlighted by (Wadhwa, et al. 2007). However, ethnic partners appear to play an even more important role.

We then compute conditional statistics of the founder's ethnicity based on the partner's ethnicity. Column three labeled "Companies where (at least) one founder has ethnicity if VC firm has (at least) one partner with ethnicity" reports the frequency of companies for which a founder shares the same ethnicity as the investing VC firm. This variable is identical to our focal variable "Same Ethnicity" that we use in our regression analysis, except it reports statistics separately for each ethnic group whereas "Same Ethnicity" aggregates this data across all ethnicities.

Comparing across the third column and the fourth column, labeled "Companies where (at least) one founder has ethnicity if VC firm does not have (at least) one partner with ethnicity", reveals that the 
conditional probabilities of an ethnic founder are overall higher if the partner shares the same ethnicity. Column five reports the results of a Wilcoxon test, and we find that the difference between columns four and five is significant for the three most common ethnicities: Jewish, Indian and Chinese. This is evidence consistent with the argument that ethnic ties matters for $\mathrm{VC}$ investments.

Empirical Strategy. We next conduct a more careful empirical testing of the importance of ethnic ties. Our tests proceed in two steps. First, we analyze how the existence of an ethnic tie relates to the likelihood that a company and a VC firm form a match (i.e., the extensive margin of the investment decision). Second, we analyze how the existence of an ethnic tie relates to the nature of the VC firmcompany match, conditional on one having taken place (i.e., the intensive margin). We here analyze whether the $\mathrm{VC}$ firm took a board seat, the timing of its first investment, the scope of its overall investment, and the design of the financial contract.

To study each of the above phenomena, we run a series of regressions where the dependent variable captures the focal dimension of the VC firm's investment and the key independent variable is "Same Ethnicity". In our baseline specifications, we include fixed effects of the year of the VC firm's first investment in the company, company location (50 US state dummies) and industry (10 dummies based on VentureEconomics 10-segment classification). These controls are included to capture other company characteristics that may correlate with an ethnic tie. We also include "VC IPO Experience" to capture differences in VC firm investment behavior that are related to reputation/skill rather than ethnicity. For OLS regressions, we cluster residuals by both company and VC firm (Petersen, 2009). For other regression types, we cluster residuals by firm. In untabulated regressions we instead cluster by firm. Results remain unchanged.

In addition to our baseline specifications, we run OLS fixed effect regressions that include company fixed effects. These specifications allow us to rule out the influence of any company-specific factors that may correlate with ethnic ties. Moreover, they shed direct light on whether a VC firm with an ethnic match invests differently than other VC firms investing in the same company. This within- 
company comparison is arguably more interesting than the baseline specification, because a company cannot change the ethnic composition of its team of founders. We also run OLS fixed effect regressions that include VC firm fixed effects. These specifications rule out the influence of any VC-specific factors that may correlate with ethnic ties. We can also use this within-VC firm comparison to study whether the VC firm invests differently in companies where an ethnic tie is present than it does in other companies. On the whole, we find qualitatively similar results in the baseline specifications without fixed effects, the specifications with company fixed effects, and specifications with company fixed effects.

One may argue that the many dimensions of the VC firm's investment in a company are highly correlated with whether the VC firm took a board seat, which in turn may be related to an ethnic tie (we empirically validate this latter relationship). We account for the influence of board seats. In our regressions using the full sample we include "VC Board Seat $(1=Y e s, 0=N o)$ " as a control variable. We also, in a separate set of regressions, restrict our sample to a subset of VC firm-company pairs for which the $\mathrm{VC}$ firm took a board seat. We find qualitatively similar results for the full sample and the board seat subsample.

\section{Results on Matching}

Matching. Table 3 presents regression results on how ethnic ties matter for the likelihood that the company and the $\mathrm{VC}$ firm form a match. To run these tests, we need to contrast the prevalence of ethnic ties for the matches that were actually formed to those for matches that could have been formed but were not. Thus, we need to identify counterfactual matches for each of the 9,079 actual pairs in our sample. We use data from VentureEconomics to find such counterfactual matches. Specifications 1 through 4 present results where the counterfactual sample includes all investments made by another VC in the same month and (10-segment) industry. Specification 5 through 8 present results where the counterfactual sample includes all investments made by another VC in the same month, (10-segment) industry, and US state. We note that the coefficient on "Same Ethnicity" is positive and significant in all specifications, confirming that ethnic ties matters for which matches are formed in the US VC industry. 


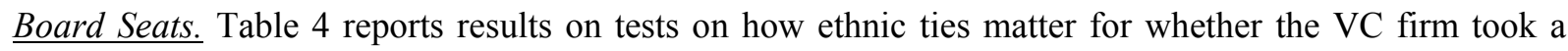
board seat, conditional on it making an investment. Again, we find the coefficient on "Same Ethnicity" to be positive and significant in all specifications. Because the result holds even when we include company fixed effects (specification 3), it cannot be explained by some companies being overall more likely to report the composition of their board. Similarly, because the result holds even when we include VC firm fixed effects (specification 4), the result cannot be explained by some VC firms being more likely to take board seats in all of their investments. Rather, the result shows that VC firms become more involved in a portfolio company if they have an ethnic tie with its founders. An unreported comparison of means shows that the difference for VC involvement is economically significant: a VC firm with an ethnic tie has a 74\% likelihood of taking a board, versus $58 \%$ for other VC firms.

Timing of Investment. Table 5 reports results on ethnic ties and the VC firm's timing of its investment. In Panel A, the dependent variable is "In (1 + Company Age First Time VC Invested in Company)." We find that in the presence of an ethnic tie, the VC firm invests in younger companies. In Panel B, we find similar results using the dependent variable "VC Invested in First Round of Company ( $1=$ Yes, $0=N o$ )." An unreported comparison of means shows that the difference for $\mathrm{VC}$ timing is also economically significant. With an ethnic tie, a VC firm has a 54\% likelihood of investing in the first round, versus $44 \%$ for other VC firms.

Scope of VC Investment. Table 6 reports results on ethnic ties and the scope of the VC firm's investment. The dependent variable is "In $(1+$ Number of Rounds VC Invested in Company)" in Panel A, and "In $(1+$ Total Dollar Amount VC Invested in Company)" in Panel B. We find positive (and significant in most specifications) coefficients on "Same Ethnicity", confirming the argument that investments with an ethnic tie last over more rounds and involve larger dollar amounts. An unreported comparison of means shows 
that the average VC firm with an ethnic tie invests $\$ 12$ million across 2.2 rounds, versus $\$ 8.9$ million across 2.2 rounds.

Financial Contract. Table 7 reports results on how ethnic ties relate to the financial contract used in the investment. In Panel A, the dependent variable is "In (1+Pre-Money Valuation)". We find that the VC firm paid lower pre-money valuations when its partner(s) had an ethnic tie with the company's founder(s). In other words, for a given dollar investment amount the $\mathrm{VC}$ received a smaller equity stake in the presence of an ethnic tie. An unreported comparison of means shows a VC firm with an ethnic tie pays an average pre-money valuation of $\$ 70$ million, versus $\$ 58$ million for other VC firms.

In Panel B, the dependent variable is "Downside Protection Index (Bengtsson and Sensoy, 2011)." We find that contracts are more entrepreneur-friendly for investments with an ethnic tie. These results are not significant when we include company fixed effects (specifications 3 and 7), which is not surprising given the weak statistical power of such tests. ${ }^{8}$ An unreported comparison of means shows that the mean Downside Protection Index is about one third of a standard deviation lower (4.27 versus 4.73 ) when the VC firms has an ethnic tie.

Summary of Results on Matching. Our empirical tests present strong evidence that ethnic ties matter in the U.S. VC industry. We find that the existence of an ethnic tie increases the likelihood that the company and the VC firm form a match (i.e., the extensive margin of the investment decision) and makes the VC firm invest earlier, more and using more favorable to the entrepreneur pricing/terms (i.e., the extensive margin). Because these results hold in specifications with company fixed effects, we infer that the influence of shared ethnicity cannot be explained by an omitted company characteristic control, but rather reflects the behavior of the focal VC firm as compared to other VC firms investing in the same company.

\footnotetext{
${ }^{8}$ We calculate the dependent variables for each company-VC firm pair by calculating the average pre-money valuation and Downside Protection Index, respectively, over all the rounds in which the VC invested. With company fixed effects, the only source of variation comes from the fact that different VC firms invested in different rounds. However, this variation is low because the pre-money valuations and contract terms are serially correlated across rounds. Amplifying this problem is the fact that data on these variables are often not reported for our sample.
} 
Similarly, because the results hold in specifications with VC firm fixed effects, we infer that omitted VC characteristics are not the explanation. The results reflect the behavior of the focal VC firm in its investments with an ethnic tie as compared to its investments without such ties.

We next turn to discussing the possible rationales for ethnic matching, and then present our tests of which rationales are most consistent with the data.

\section{Rationales for Matching}

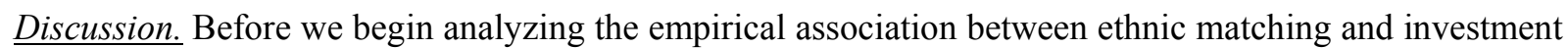
outcomes, it is important to note that matching in the VC context has two distinct goals. First, the partner and founder seek to increase the likelihood that the startup will turn into a successful company, ideally that can be exited through an Initial Public Offering (IPO). Success is the ultimate prize for both parties: The partner is able to exit the investment, receives monetary payoffs (from carried interest), and strengthens his or her standing in the VC community. The founder also receives payoffs, and may enjoy private benefits from the successful outcome itself or from being subsequently "self-employed" in a successful company.

A second goal of matching is that the partner and the founder want to minimize the transaction costs surrounding the formation and maintenance of their relationship. For the partner, these transaction costs include expenses incurred during due diligence, legal fees for contract negotiation, expenses for travelling to board meetings, etc. Another transaction cost, and arguably the most important one in practice, is the partner's opportunity cost of time. The VC firm must carefully economize on how much time the partner spends on each investment, because otherwise it risks forgoing other promising investments and provide inadequate monitoring/support to other portfolio companies. For the founder, the opportunity cost of time is also very valuable. If the founder spends too much time dealing with a given $\mathrm{VC}$ firm, then he or she may ignore other investors and not put in sufficient efforts on growing the company. 
Matching based on shared partner and founder ethnicity would create value in a VC investment if it were to achieve either or both of the goals discussed above. Value creation could occur due to easier communication, more efficient sharing of soft information or more trust among members of the same ethnic subgroup. We label such rationales for matching as "good".

Conversely, a match based on shared ethnicity would destroy value if the likelihood of a successful outcome decreased and/or transaction costs pertaining to relationship were to increase. An obvious question to ask is why a partner and a founder would chose to form a co-ethnic match if it would result in value destruction. One possibility is that they have a behavioral bias that makes them overestimate the skills and capabilities of people who share their ethnicity. Alternatively, they may overestimate the benefits of forming a match with such people. Another possibility, which we discussed in detail in Section 1, is that a too high degree of similarity between founders and partners may result in group-think during board meetings. Finally, founders and partners may respond to pressure from their ethnic subgroup to do business with members of the same subgroup. We label such rationales as "bad", since matching based on them does not create value.

Empirical Strategy and its Limitations. We analyze data on investment outcomes to test whether co-ethnic matches in the VC industry are formed based on "good" (i.e., value-increasing) or "bad" (i.e., valuedestroying) rationales. We define an investment as successful if the company had an IPO, and then correlates this investment outcome with our focal independent variable "Same Ethnicity". In our robustness tests, we also define an investment as successful if the company was acquired or merged with another company. In addition to "Same Ethnicity", we include controls for investment year, industry and location (i.e., state dummies). We also include as controls the variables we studied in previous tables: company age at VC's first investment, whether the VC invested in the first round, number of rounds in which the VC invested, dollar amount the VC invested in the company, and pre-money valuation. ${ }^{9} \mathrm{As}$

\footnotetext{
${ }^{9}$ We exclude "Downside Protection Index (Bengtsson and Sensoy, 2011)" because this variable is only reported for a small subset of our sample, creating problems with statistical power and representativeness.
} 
such, we study whether the VC firm realized a more/less successful company outcome conditional on the intensity of its investment. In some tests we also control for two other variables, "log Distance between Company and VC (miles)" and "Patents 5 years after first VC round ( $1=Y e s, 0=N o)$ ", that may be correlated with company outcomes

Although our analysis of outcomes allows us to shed some light on the rationale behind ethnic matching, it has four limitations. The first limitation is that we can only study investment outcomes for investments in our sample made prior to 2003. Our data is collected at 2009, so this cutoff ensures that each successful company had sufficient time to realize its exit. The surviving sample includes 4,812 observations, of which 2,499 are matches where the VC firm takes a board seat.

The second limitation is that our tests cannot speak to the association between ethnic matching and transaction costs, such as the VC firm's selection and monitoring efforts. Despite their real-world importance, these costs are not observable features of the VC investment. Therefore, it remains possible that ethnic matching could be formed based on the "good" rationale of lower transaction costs even if such investments were associated with worse investment outcomes.

The third limitation is that the measure of a successful investment outcome is incomplete and noisy in that attaining an initial public offering is only one coarse measure of entrepreneurial performance. The private nature of the companies and investors that we study imply a lack of detailed data on investment outcomes (e.g., IRR or dollar payoff from each investment). An additional challenge is that we are unable to perfectly control for other determinants of an IPO, such as the quality of the founder's idea or the nature of the startup's other assets. This follows from the fact that we cannot include company fixed effects in the outcome regressions, because our measure of investment outcome is identical for all VC firms investing in the company.

The fourth, and arguably most problematic, limitation is that our tests confound selection and treatment effects. Although this problem plagues most existing studies of the VC industry (see Sorensen, 2007, for a discussion), it is particularly severe in our context because selection and treatment have 
opposite effects on investment outcomes. Consider a simple theoretical framework where the "good" rationales for ethnic matching dominate the "bad" rationales, and where the VC firm wishes to maximize the ex-post quality of its portfolio. Accordingly, the VC firm would base its investment choices on the exante quality of available startups and the value creation specific to each matching. In equilibrium, the VC firm would select some co-ethnic investments in lower quality startups over other investments in higher quality startups. Because of such offsetting selection effects, it is difficult to empirically isolate the treatment effect (i.e, value-creation) associated with ethnic matching.

\section{Results on Investment Outcomes.}

Table 8 presents our results on the association between co-ethnic ties and company outcomes. The estimation technique is OLS with residuals clustered on both VC firm and company, except in specifications 3 and 6 where VC firm fixed effects are included. All results are qualitatively similar in unreported tests where the estimation technique is logit, and residuals clustered on VC firm.

In Panel A, the dependent variable is "Company IPO Exit $(1=$ Yes, $0=N o$ )". This variable is 1 if the company had a successful IPO exit, and is 0 otherwise. We find that an IPO outcome is less common when the VC firm has a co-ethnic tie with the company. This result holds in specifications with different controls, including those with VC firm fixed effects, and also for the subsample of investments where the VC firm took a board seat. We obtain qualitatively similar coefficient estimates in Panel B, where the dependent variable is "Company IPO or M\&A Exit $(1=Y e s, 0=N o)$ ". This variable is 1 if the company either had a successful IPO or M\&A exit, and is 0 otherwise. However, the results are only statistically significant in specifications with the subsample where the VC firm took a board seat. We conclude from these results that co-ethnic ties appear to be associated with worse investment outcomes. Similar results are obtained by Gompers et al. (2012) who study company outcomes for co-ethnic matches between VC firms in investment syndicates. Combined, these findings point to ethnic matching hampering company performance and, as a result, investor returns. 


\section{Concluding Discussion}

This paper aims to fill a gap in the literature regarding the process by which entrepreneurial startups get matched with VC firms. We investigate the empirical relevance of personal similarity in the U.S. VC market, focusing on ethnicity. Our results show that person-based matching based on a shared ethnicity is a strong predictor of a range of $\mathrm{VC}$ investment behavior.

It is useful to situate the results reported here within the context of the literatures on $\mathrm{VC}$ and new venture team formation. While we are not able to identify the exact mechanism driving the matching process between VC investors and entrepreneurs, we can relate the plausible mechanisms in our context to those found in the associated literature examining the reasons for VC syndication (e.g., Lerner, 1994; Brander, et al., 2002) and the consequences of varied VC syndicates (Hochberg et al., 2007). A starting point is the observation that financial constraints are not likely to be the primary driver of VC syndication since the magnitude of VC investments, especially in early stage rounds, are a small fraction of the typical VC fund size. Studies examining the impetus for investment syndication broadly analyze selection-based and value creation-based reasons (other theories do exist, but we highlight these theories since they are most germane to our discussion).

In selection-based accounts, VC syndication takes place to facilitate due diligence and assessment processes under the logic that different investors have different opinions and/or expertise with regard to identifying the most promising venture opportunities and entrepreneurs. An information mechanism therefore underlies the selection-based argument in that investor teams are assembled to maximize the chance of selecting the most promising startups in which to invest. Extending team composition from the strictly within-investor realm into the investor-entrepreneur formation realm, we find support for the information transmission mechanism in that ethnic ties may be pipes along which information can be shared with the result of dampened information asymmetry. The form of the information transmitted could be direct exchange among the parties, norms of trust within a social network, and/or a governance mechanism enabled by shared social networks. In this governance mechanism, defecting behavior will be more costly within a social network because it is likely to be broadcast more quickly and completely 
within than across social networks. We are unable to distinguish which of these effects may be operating in this context.

The information and value-added rationale for team formation are not mutually exclusive, however, as researchers in the VC literature acknowledge (Brander et al., 2002; Hsu, 2004; Sorenson, 2007; Chemmanur et al., 2011). Our results are consistent with this view, as we find that co-ethnicity significantly explains the likelihood of a VC-entrepreneur match.

While our primary aim is in examining the VC-entrepreneur matching context, an area we believe is both important and understudied, it is possible to speculate about how general the co-ethnicity effects are likely to be. We have chosen a context in which there is constrained matching: a given VC partner can only sit on a certain number of boards at a given time, and a given entrepreneurial company can only have a certain number of VC partners on its board. Like other matching contexts in which there is a zero-sum choice involved in that matching with one entity means foregoing other opportunities (e.g., the marriage, job, and college markets), assessing the role of personal similarity in explaining matching seems fairly generic.

Our empirical setting of the VC-entrepreneur matching context also involves a different production process distinct from other settings in which social networks play a role, such as common school ties between mutual fund managers and portfolio company managers (Cohen et al., 2008). The VCentrepreneur context has the potential to involve both selection and value-added, and it is the latter process in particular which highlights the role of co-production and makes VC-entrepreneur matching a double-sided selection process. These features distinguish our empirical setting from other investment contexts such as mutual fund portfolio selection.

We end with a few thoughts for future avenues of research given the results reported here. First, examining the possible effects more comprehensively would be interesting. For example, how does personal similarity (including co-ethnicity) affect entrepreneur-VC interaction during the pre-investment due diligence process and the post-investment board involvement, and with what consequences? Second, what are the welfare and efficiency implications of matching in the market for entrepreneurial finance? 
Given the average characteristics of venture partners in the sample, coupled with the role of personal similarity between entrepreneurial founder and venture partner in explaining match likelihood, issues of efficiency naturally arise. Our aim in this paper was to better understand matching in the market for entrepreneurial finance; we hope that future work will extend this research by delving into these and other questions of the implications of this matching process.

\section{References}

Agrawal, A., D. Kapur, and J. McHale (2007). "Birds of a Feather-Better Together? Exploring the Optimal Spatial Distribution of Ethnic Inventors,” NBER working paper no. 12823 (2007).

Akerlof, G. (1970). “The Market for 'Lemons': Quality Uncertainty and the Market Mechanism,” Quarterly Journal of Economics, 84: 488-500.

Becker, G. (1996). "Preferences and Values" in G. Becker, ed., Accounting for Tastes, Harvard University Press, Cambridge, MA. pp. 3-23.

Bengtsson, O. and B. Sensoy. (2011). "Investor Abilities and Financial Contracting: Evidence from Venture Capital," Journal of Financial Intermediation, 20: 477-502.

Berger, A., N. Miller, M. Petersen, R. Rajan, and J. Stein, 2005, Does Function Follow Organizational Form? Evidence From the Lending Practices of Large and Small Banks," Journal of Financial Economics, 2: $237-269$.

Brander, J., R. Amit and W. Antweiler (2002). "Venture-Capital Syndication: Improved Venture Selection vs. the Value Added Hypothesis," Journal of Economics and Management Strategy, 11: 423452.

Casella, A. and J. Rauch (2002). “Anonymous Market and Group Ties in International Trade," Journal of International Economics, 58: 19-47.

Chemmanur, T., K Krishnan and D. Nandy (2011). "How Does Venture Capital Financing Improve Efficiency in Private Firms? A Look Beneath the Surface," Review of Financial Studies, 24: 4037-4090.

Chen, H., P. Gompers, and A. Kovner (2010). "Buy Local? The Geography of Venture Capital,” Journal of Urban Economics, 67: 90-102.

Cohen, L., A. Frazzini, and C. Malloy (2008). "The Small World of Investing: Board Connections and Mutual Fund Returns,” Journal of Political Economy, 116: 951-979.

Esser, J. (1998). “Alive and Well After 25 Years: A Review of Groupthink Research,” Organizational Behavior and Human Decision Processes, 73: 116-141. 
Fisman, R. (2003). "Ethnic Ties and the Provision of Credit: Relationship-Level Evidence from African Firms," Advances in Economic Analysis \& Policy, 3, 4.

Fried, V. and R. Hisrich (1994). "Toward a Model of Venture Capital Investment Decision Making," Financial Management, 3: 28-47.

Glaeser, E., D. Laibson, J. Scheinkman, C. Soutter. (2000). "Measuring Trust,” Quarterly Journal of Economics, 115: 811-846.

Gompers, P., V. Mukharlyamov and Y. Xuan (2012). “The cost of friendship,” NBER Working Paper 18141.

Granovetter, M. (1973). “The Strength of Weak Ties,” American Journal of Sociology, 78: 1360-1380.

Greif, A. (1989). "Reputation and Coalitions in Medieval Trade: Evidence on the Maghribi Traders," Journal of Economic History, 49: 857-882.

Greif, A. (1993). "Contract Enforceability and Economic Institutions in Early Trade: the Maghribi Traders' Coalition.” American Economic Review, 83: 525-48.

Guiso, L., P. Sapienza, and L. Zingales. (2006). "Does Culture Affect Economic Outcomes?” Journal of Economic Perspectives, 20: 23-48.

Hegde and Tomlinson (2011). "Can Birds of a Feather Fly Together? Evidence for the Economic Payoffs of Ethnic Homophily,” Working Paper, New York University.

Hellmann, T. and M. Puri (2002). "Venture Capital and The Professionalization of Start-up Firms: Empirical Evidence.” Journal of Finance, 57: 169-197.

Hochberg, Y., A. Ljungqvist and Y. Lu (2007). "Whom You Know Matters: Venture Capital Networks and Investment Performance," Journal of Finance, 62: 251-301.

Hochberg, Y., A. Ljungqvist and Y. Lu (2010). "Networking as a Barrier to Entry and the Competitive Supply of Venture Capital,” Journal of Finance, 65: 829-859.

Hsu, D. (2004). “What Do Entrepreneurs Pay for Venture Capital Affiliation?” Journal of Finance, 59: $1805-1844$.

Hsu, D. (2007). "Experienced Entrepreneurial Founders, Organizational Capital, and Venture Capital Funding," Research Policy, 36: 722-741.

Huang, Y., L. Jin and Y. Qian (forthcoming). "Does Ethnicity Pay? Evidence from Overseas-Chinese FDI in China," Review of Economics and Statistics, forthcoming.

Iyer, R. and A. Schoar (2010). “Are There Cultural Determinants of Entrepreneurship?" in J. Lerner and A. Schoar, eds., International Differences in Entrepreneurship. University of Chicago Press. 
Janis, I. (1982). Groupthink: Psychological Studies of Policy Decisions and Fiascoes. Second edition. Houghton Mifflin: New York.

Kerr, W. (2008). "Ethnic Scientific Communities and International Technology Diffusion" Review of Economics and Statistics, 90: 518-537.

Kaplan, S., B. Sensoy and P. Stromberg (2002), "How Well Do Venture Capital Databases Reflect Actual Investments?," University of Chicago, Ohio State University, Swedish Institute for Financial Research, Working Paper.

Kaplan, S. and P. Stromberg (2003). "Financial Contracting Meets the Real World: An Empirical Analysis of Venture Capital Contracts, Review of Economic Studies, 70: 281-315.

Kaplan, S. and P. Stromberg (2004). "Characteristics, Contracts, and Action: Evidence from Venture Capital Analyses," Journal of Finance, 59: 2177-2210.

Landa, J. (1994). Trust, Ethnicity and Identity: Beyond the New Institutional Economics of Trading Networks, University of Michigan Press, Ann Arbor, MI.

Lerner, J. (1994). "The Syndication of Venture Capital Investments," Financial Management, 23: 16-27.

Lerner, J. (1995). "Venture Capitalists and the Oversight of Private Firms," Journal of Finance, 50: 301318.

Petersen, M. and R. Rajan (2002). "Does Distance Still Matter? The Information Revolution in Small Business Lending,” Journal of Finance, 57: 2533-2570

Petersen (2009). "Estimating Standard Errors in Finance Panel Data Sets: Comparing Approaches," Review of Financial Studies, 22: 435-480.

Ruef, M., H. Aldrich and N. Carter (2003). "The Structure of Founding Teams: Homophily, Strong Ties, and Isolation Among US Entrepreneurs,” American Sociological Review, 68: 195-222.

Saxenian (1999). Silicon Valley's New Immigrant Entrepreneurs. Public Policy Institute of California: San Francisco, CA.

Saxenian (2006). The New Argonauts: Regional Advantage in a Global Economy. Harvard University Press: Cambridge, MA.

Sorensen, M. (2007). "How Smart is Smart Money? A Two-sided Matching Model of Venture Capital," Journal of Finance. 62: 2725-62.

Sorensen (2008). "Learning by Investing: Evidence from Venture Capital," Columbia University, Working Paper.

Stein, J. (2002). “Decentralized versus Hierarchical Firms", Journal of Finance, 57: 1891-1921. 
Stuart, T. and O. Sorenson (2001). "Syndication Networks and the Spatial Distribution of Venture Capital Investments," American Journal of Sociology, 106: 1546-88.

Tetlock, P. (1979). "Identifying Victims of Groupthink from Public Statements of Decision Makers," Journal of Personality and Social Psychology, 37: 1314-1324.

Tetlock, P., R. Peterson, C. McGuir, S. Chang, P. Feld. (1992). "Assessing Political Group Dynamics: A Test of the Groupthink Model," Journal of Personality and Social Psychology, 63: 403-425.

Wadhwa, V., A. Saxenian, B. Rissing, G. Gereffi. (2007). “America's New Immigrant Entrepreneurs," Master of Engineering Management Program of Duke University publication. 


\section{Table 1 - Sample Overview}

We obtain from VentureEconomics 10,081 listed actual matches between a VC partner and a company founder. We aggregate these individual-based matches to VC and company levels, and create our sample of 9,079 "VC-Company Matches". This sample includes both matches where the VC invested and took a board seat and matches where the VC invested but did not take a board seat. We identify the partner's ethnicity from any investment made by the VC firm concurrently with an investment in the focal company. Panel B reports statistics for key variables and Panel $C$ for variables used as additional controls. VC IPO Experience is the historical fraction of the firm's portfolio companies that have had an IPO exit. Downside Protection Index and Pre-Money Valuation reflect average for all rounds in which VC invested (and data is available).Data on Downside Protection Index come from VCExperts. The sample for company exits is restricted to investment made prior to 2003, to ensure sufficient time for company to realize exit (our data is collected to 2009).

\section{Panel A: Sample Overview}

VC Partner - Company Founder Matches 10081

Unique Company Founders 5093

Unique Companies 3125

Unique VC Partners 2361

Unique VCs 966

VC-Company Matches $\quad 9079$

Panel B: Summary Statistics of Key Variables (Sample is VC-Company Matches)

$\begin{array}{lccc} & \underline{\text { Obs }} & \underline{\text { Mean }} & \underline{\text { Std. Dev. }} \\ \text { Same Ethnicity } & 9079 & 5.2 \% & 22.2 \% \\ \text { VC IPO Experience } & 9079 & 15.1 \% & 10.9 \% \\ \text { VC Board Seat (1=Yes, 0=No) } & 9079 & 59 \% & 49.2 \% \\ \text { Company Age First Time VC Invested in Company (years) } & 8827 & 2.9 & 3.4 \\ \text { VC Invested in First Round of Company (1=Yes, 0=No) } & 9079 & 44.2 \% & 49.7 \% \\ \text { Number of Rounds VC Invested in Company } & 9079 & 2.2 & 2.2 \\ \text { Total Dollar Amount VC Invested in Company (in \$m) } & 9079 & 9.1 & 14.0 \\ \text { Pre-Money Valuation (in \$m) } & 4815 & 58.1 & 97.0 \\ \text { Downside Protection Index (Bengtsson and Sensoy, 2011) } & 1923 & 4.7 & 1.5 \\ \text { IPO Exit (1=Yes, 0=No) } & 4934 & 16.7 \% & 37.3 \% \\ \text { IPO or M\&A Exit (1=Yes, 0=No) } & 4934 & 57.3 \% & 49.5 \%\end{array}$

Panel C: Summary Statistics of Additional Controls (Sample is VC-Company Matches)

Distance between Company and VC (miles)

$\underline{\text { Obs }} \quad \underline{\text { Mean }}$

$8804 \quad 812.8$

$\underline{\text { Std. Dev. }}$

Patents 5 years after first VC round ( $1=$ Yes, $0=$ No)

$9079 \quad 47.7 \%$

1015.2 


\section{Table 2 - Ethicities}

This table reports the ethnicity for the VC partner, company founder, and company founder by whether the partner and founder ethnicities were the same or different. We aggregate individual-based matches to VC and company levels, so one observation is a unique match of a VC and a company. Sample size is 9079. Difference between the subsamples is reported and significance tested with a Wilcoxon test. *** marks significance at $1 \%$, and ** significance at $5 \%$.

VC firms where (at least) one partner has ethnicity
II

Companies where (at least) one founder has ethnicity

\section{III}

Companies where (at least) one founder has ethnicity if VC firm has (at least) one partner with ethnicity

\section{IV}

Companies where (at least) one founder has ethnicity if VC firm does not have (at least) one partner with ethnicity

\section{Jewish}

Indian

Chinese

Korean

Hispanic

Russian

Japanese

Vietnamese

\begin{tabular}{|c|c|c|c|c|}
\hline $19.7 \%$ & $8.2 \%$ & $9.6 \%$ & $7.9 \%$ & $* *$ \\
\hline $14.2 \%$ & $9.2 \%$ & $15.2 \%$ & $8.2 \%$ & $* * *$ \\
\hline $5.5 \%$ & $5.0 \%$ & $9.8 \%$ & $5.0 \%$ & $* * *$ \\
\hline $3.5 \%$ & $1.4 \%$ & $1.3 \%$ & $1.4 \%$ & \\
\hline $3.9 \%$ & $1.6 \%$ & $2.0 \%$ & $1.5 \%$ & \\
\hline $1.7 \%$ & $1.6 \%$ & $1.3 \%$ & $1.6 \%$ & \\
\hline $0.9 \%$ & $0.5 \%$ & $0.0 \%$ & $0.5 \%$ & \\
\hline $0.3 \%$ & $0.9 \%$ & $0.9 \%$ & $0.9 \%$ & \\
\hline
\end{tabular}




\section{Table 3 - VC Investment Decision}

Sample is actual and counterfactual VC-Company matches. OLS regressions where the dependent variable is 1 if the VC invested in the company (i.e., an "Actual Match") and is 0 if the VC invested in another company in same industry (10-segment) and month (i.e., a "Counterfactual Match"). In specifications 5-8 we also include the criteria that the VC invested in another company in the same state. Specifications 1 and 5 are logit regressions with residuals clustered by company (we obtain similar results if we cluster by VC). VC IPO Experience is the historical fraction of the firm's portfolio companies that have had an IPO exit. Specifications 2 and 6 are OLS regressions with residuals clustered by both VC and company (Petersen, 2009). Specifications 3 and 7 are fixed effect OLS with company fixed effects. Specifications 4 and 8 are fixed effect OLS with VC fixed effects. F.E. VC Year Investment are dummies for the year the VC first invested in the company. F.E. Company Industry are 10-segment VentureEconomics dummies. F.E. Company State are dummies for the U.S. of the company's headquarter. ${ }^{* * *}$ marks significance at $1 \%$, and ${ }^{* *}$ significance at ror

Dependent Variable:

VC Invested in Company $(1=$ Yes, $0=$ No)

\begin{tabular}{|c|c|c|c|c|c|c|c|c|}
\hline Specification & $\underline{1}$ & $\underline{2}$ & $\underline{3}$ & $\underline{4}$ & $\underline{5}$ & $\underline{6}$ & $\underline{7}$ & $\underline{8}$ \\
\hline Same Ethnicity & $\begin{array}{c}0.257 * * * \\
{[0.046]}\end{array}$ & $\begin{array}{c}0.012 * * * \\
{[0.005]}\end{array}$ & $\begin{array}{c}0.016^{* * *} \\
{[0.003]}\end{array}$ & $\begin{array}{c}0.012^{* * *} \\
{[0.002]}\end{array}$ & $\begin{array}{c}0.202^{* * *} \\
{[0.048]}\end{array}$ & $\begin{array}{l}0.020^{* *} \\
{[0.009]}\end{array}$ & $\begin{array}{c}0.023 * * * \\
{[0.006]}\end{array}$ & $\begin{array}{c}0.019 * * * \\
{[0.006]}\end{array}$ \\
\hline VC IPO Experience & $\begin{array}{c}0.189 * * \\
{[0.086]}\end{array}$ & $\begin{array}{l}0.008^{* *} \\
{[0.004]}\end{array}$ & $\begin{array}{c}0.007 \\
{[0.007]}\end{array}$ & & $\begin{array}{c}-0.01 \\
{[0.101]}\end{array}$ & $\begin{array}{c}-0.002 \\
{[0.011]}\end{array}$ & $\begin{array}{c}0.006 \\
{[0.018]}\end{array}$ & \\
\hline Sample & \multirow{2}{*}{\multicolumn{4}{|c|}{$\begin{array}{l}\text { Actual and Counterfactual VC-Company } \\
\text { Matches } \\
\text { Same month and industry (10-segment } \\
\text { VentureEconomics) }\end{array}$}} & \multirow{2}{*}{\multicolumn{4}{|c|}{$\begin{array}{l}\text { Actual and Counterfactual VC-Company } \\
\text { Matches } \\
\text { Same month, industry (10-segment } \\
\text { VentureEconomics) and state }\end{array}$}} \\
\hline Criteria Counteractual Match & & & & & & & & \\
\hline Observations & 192423 & 192423 & 192423 & 192423 & 64671 & 64671 & 64671 & 64671 \\
\hline R-squared & 0.07 & 0.04 & 0.01 & 0.03 & 0.15 & 0.15 & 0.01 & 0.11 \\
\hline Regression Type & Logit & OLS & OLS & OLS & Logit & OLS & OLS & OLS \\
\hline F.E. VC Year Investment & Yes & Yes & Yes & Yes & Yes & Yes & Yes & Yes \\
\hline F.E. Company Industry & Yes & Yes & N.A. & Yes & Yes & Yes & N.A. & Yes \\
\hline F.E. Company State & Yes & Yes & N.A. & Yes & Yes & Yes & N.A. & Yes \\
\hline F.E. Company & No & No & Yes & No & No & No & Yes & No \\
\hline F.E. VC & No & No & No & Yes & No & No & No & Yes \\
\hline
\end{tabular}




\section{Table 4 - VC Board Seat}

Sample is actual VC-Company matches. The dependent variable is 1 if the VC invested and took a board seat, and is 0 if the VC invested but did not take a board seat. VC IPO Experience is the historical fraction of the firm's portfolio companies that have had an IPO exit. Specification 1 is a logit regression with residuals clustered by company (we obtain similar results if we cluster by VC). Specification 2 is an OLS regression with residuals clustered by both VC and company (Petersen, 2009). Specification 3 is a fixed effect OLS with company fixed effects. Specification 4 is a fixed effect OLS with VC fixed effects. F.E. VC Year Investment are dummies for the year the VC first invested in the company. F.E. Company Industry are 10-segment VentureEconomics dummies. F.E. Company State are dummies for the U.S. of the company's headquarter. *** marks significance at $1 \%$, and ${ }^{* *}$ significance at $5 \%$.

Dependent Variable:

VC Board Seat $(1=$ Yes, $0=$ No $)$

Specification

$\underline{1}$

$\underline{2}$

$\underline{3}$

$\underline{4}$

Same Ethnicity

$0.724 * * *$

$0.154 * * *$

$0.193^{* * *}$

$0.111^{* * *}$

[0.109]

[0.022]

[0.032]

[0.024]

VC IPO Experience

$\begin{array}{ccc}-0.568 * * & -0.132 & -0.126 * \\ {[0.223]} & {[0.109]} & {[0.069]}\end{array}$

$[0.223] \quad[0.109] \quad[0.069]$

Sample

Observations

R-squared

Regression Type

F.E. VC Year Investment

F.E. Company Industry

F.E. Company State

F.E. Company

F.E. VC
Actual VC-Company Matches

$\begin{array}{cccc}9079 & 9079 & 9079 & 9079 \\ 0.04 & 0.05 & 0.01 & 0.05 \\ & & & \\ \text { Logit } & \text { OLS } & \text { OLS } & \text { OLS } \\ \text { Yes } & \text { Yes } & \text { Yes } & \text { Yes } \\ \text { Yes } & \text { Yes } & \text { N.A. } & \text { Yes } \\ \text { Yes } & \text { Yes } & \text { N.A. } & \text { Yes } \\ \text { No } & \text { No } & \text { Yes } & \text { No } \\ \text { No } & \text { No } & \text { No } & \text { Yes }\end{array}$




\section{Table 5 - VC Timing of Investment}

Sample is actual VC-Company matches. In Panel A, the dependent variable is the logarithm of the company's age at the time of the VC's investment. Specifications 1-3 include the full sample of actual VC-company matches, and specifications 4-6 includes only actual VC-company matches where the VC took a board seat. VC IPO Experience is the historical fraction of the firm's portfolio companies that have had an IPO exit. Specifications 1 and 4 are OLS regressions with residuals clustered by both VC and company (Petersen, 2009). Specification 2 and 5 are fixed effect OLS with company fixed effects. Specifications 3 and 6 are fixed effect OLS with VC fixed effects. F.E. VC Year Investment are dummies for the year the VC first invested in the company. F.E. Company Industry are 10-segment VentureEconomics dummies. F.E. Company State are dummies for the U.S. of the company's headquarter. ${ }^{* * *}$ marks significance at $1 \%$, and ${ }^{* *}$ significance at $5 \% .$.

\section{PANEL A: Company Age}

Dependent Variable:

In (1 + Company Age First Time VC Invested in Company)

Specification

$\underline{1}$

$\underline{2}$

$\underline{3}$

$\underline{4}$

$\underline{5}$

$\underline{6}$

Same Ethnicity

$\begin{array}{ccc}-0.139 * * * & -0.044 * * * & -0.097 * * * \\ {[0.041]} & {[0.013]} & {[0.033]} \\ & & \\ 0.419 * * * & 0.057 * * & \\ {[0.122]} & {[0.028]} & \\ & & \\ -0.126 * * * & -0.044 * * * & -0.111^{* * *} \\ {[0.018]} & {[0.005]} & {[0.015]}\end{array}$

VC Board Seat (1=Yes, $0=$ No)

0.005

$-0.157 * * * \quad-0.047 * * * \quad-0.131 * * *$

VC IPO Experience

Actual VC-Company Matches

Sample

8827

8827

8827

0.15

0.84

0.12

$0.275^{*}$

[0.017]

[0.041]

R-squared

OLS

OLS

OLS

F.E. VC Year Investment

Yes

Yes

Yes

F.E. Company Industry

N.A. Yes

F.E. Company State

Yes

N.A.

Yes

[0.156]

$-0.077^{*}$

Yes

Yes

No

F.E. VC

No

No

Yes

Actual VC-Company Matches with

Board Seat

$5197 \quad 5197$

5197

$0.15 \quad 0.85$

0.12

OLS

OLS

OLS

Yes

Yes

Yes

Yes

N.A. Yes

Yes N.A. Yes

No Yes No

No No Yes 


\section{Table 5 - continued}

Sample is actual VC-Company matches. In Panel B, the dependent variable is 1 if the VC invested in the company's first VC financing round, and if the VC invested only in later rounds. Specifications 1-4 include the full sample of actual VC-company matches, and specifications 5-8 include only actual VC-company matches where the VC took a board seat. VC IPO Experience is the historical fraction of the firm's portfolio companies that have had an IPO exit. Specifications 1 and 5 are logit regressions with residuals clustered by company (we obtain similar results if we cluster by VC). Specifications 2 and 6 are OLS regressions with residuals clustered by both VC and company (Petersen, 2009). Specification 3 and 7 are fixed effect OLS with company fixed effects. Specifications 4 and 8 are fixed effect OLS with VC fixed effects. F.E. VC Year Investment are dummies for the year the VC first invested in the company. F.E. Company Industry are 10-segment VentureEconomics dummies. F.E. Company State are dummies for the U.S. of the company's headquarter. ${ }^{* * *}$ marks significance at $1 \%$, and ${ }^{* *}$ significance at $5 \% .$.

\section{PANEL B: Investment in First Round}

Dependent Variable:

VC Invested in First Round of Company $(1=\mathrm{Yes}, 0=\mathrm{No})$

\begin{tabular}{|c|c|c|c|c|c|c|c|c|}
\hline Specification & $\underline{1}$ & $\underline{2}$ & $\underline{3}$ & $\underline{4}$ & $\underline{5}$ & $\underline{6}$ & $\underline{7}$ & $\underline{8}$ \\
\hline Same Ethnicity & $\begin{array}{c}0.360 * * * \\
{[0.100]}\end{array}$ & $\begin{array}{c}0.082^{* * *} \\
{[0.029]}\end{array}$ & $\begin{array}{c}0.076 * * * \\
{[0.023]}\end{array}$ & $\begin{array}{l}0.050^{* *} \\
{[0.024]}\end{array}$ & $\begin{array}{c}0.369 * * * \\
{[0.114]}\end{array}$ & $\begin{array}{c}0.086^{* * *} \\
{[0.033]}\end{array}$ & $\begin{array}{c}0.05 \\
{[0.033]}\end{array}$ & $\begin{array}{l}0.064 * * \\
{[0.029]}\end{array}$ \\
\hline VC IPO Experience & $\begin{array}{c}-2.136 * * * \\
{[0.249]}\end{array}$ & $\begin{array}{c}-0.467 * * * \\
{[0.076]}\end{array}$ & $\begin{array}{c}-0.229 * * * \\
{[0.049]}\end{array}$ & & $\begin{array}{c}-1.181^{* * *} \\
{[0.297]}\end{array}$ & $\begin{array}{c}-0.273 * * * \\
{[0.090]}\end{array}$ & $\begin{array}{c}-0.1 \\
{[0.085]}\end{array}$ & \\
\hline VC Board Seat $(1=$ Yes, $0=$ No) & $\begin{array}{c}0.885 * * * \\
{[0.047]}\end{array}$ & $\begin{array}{c}0.200 * * * \\
{[0.012]}\end{array}$ & $\begin{array}{c}0.071^{* * *} \\
{[0.009]}\end{array}$ & $\begin{array}{c}0.177 * * * \\
{[0.011]}\end{array}$ & & & & \\
\hline Sample & \multicolumn{4}{|c|}{ Actual VC-Company Matches } & \multicolumn{4}{|c|}{$\begin{array}{l}\text { Actual VC-Company Matches with Board } \\
\text { Seat }\end{array}$} \\
\hline Observations & 9079 & 9079 & 9079 & 9079 & 5357 & 5357 & 5357 & 5357 \\
\hline R-squared & 0.08 & 0.10 & 0.39 & 0.07 & 0.06 & 0.07 & 0.43 & 0.06 \\
\hline Regression Type & Logit & OLS & OLS & OLS & Logit & OLS & OLS & OLS \\
\hline F.E. VC Year Investment & Yes & Yes & Yes & Yes & Yes & Yes & Yes & Yes \\
\hline F.E. Company Industry & Yes & Yes & N.A. & Yes & Yes & Yes & N.A. & Yes \\
\hline F.E. Company State & Yes & Yes & N.A. & Yes & Yes & Yes & N.A. & Yes \\
\hline F.E. Company & No & No & Yes & No & No & No & Yes & No \\
\hline F.E. VC & No & No & No & Yes & No & No & No & Yes \\
\hline
\end{tabular}




\section{Table 6 - Scope of VC Investment}

Sample is actual VC-Company matches. In Panel A, the dependent variable is the logarithm of the number of rounds the VC invested in the company. Specifications 1-4 include the full sample of actual VC-company matches, and specifications 5-8 includes only actual VC-company matches where the VC took a board seat. VC IPO Experience is the historical fraction of the firm's portfolio companies that have had an IPO exit. Specifications 1 and 5 are negative binominal regressions with residuals clustered by company (we obtain similar results if we cluster by VC). Specifications 2 and 6 are OLS regressions with residuals clustered by both VC and company (Petersen, 2009). Specification 3 and 7 are fixed effect OLS with company fixed effects. Specifications 4 and 8 are fixed effect OLS with VC fixed effects. F.E. VC Year Investment are dummies for the year the VC first invested in the company. F.E. Company Industry are 10-segment VentureEconomics dummies. F.E. Company State are dummies for the U.S. of the company's headquarter. ${ }^{* * *}$ marks significance at $1 \%,{ }^{* *}$ significance at $5 \%$, and ${ }^{*}$ significance at $10 \%$.

\section{Panel A: Number of Rounds}

Dependent Variable: In (1 + Number of Rounds VC Invested in Company)

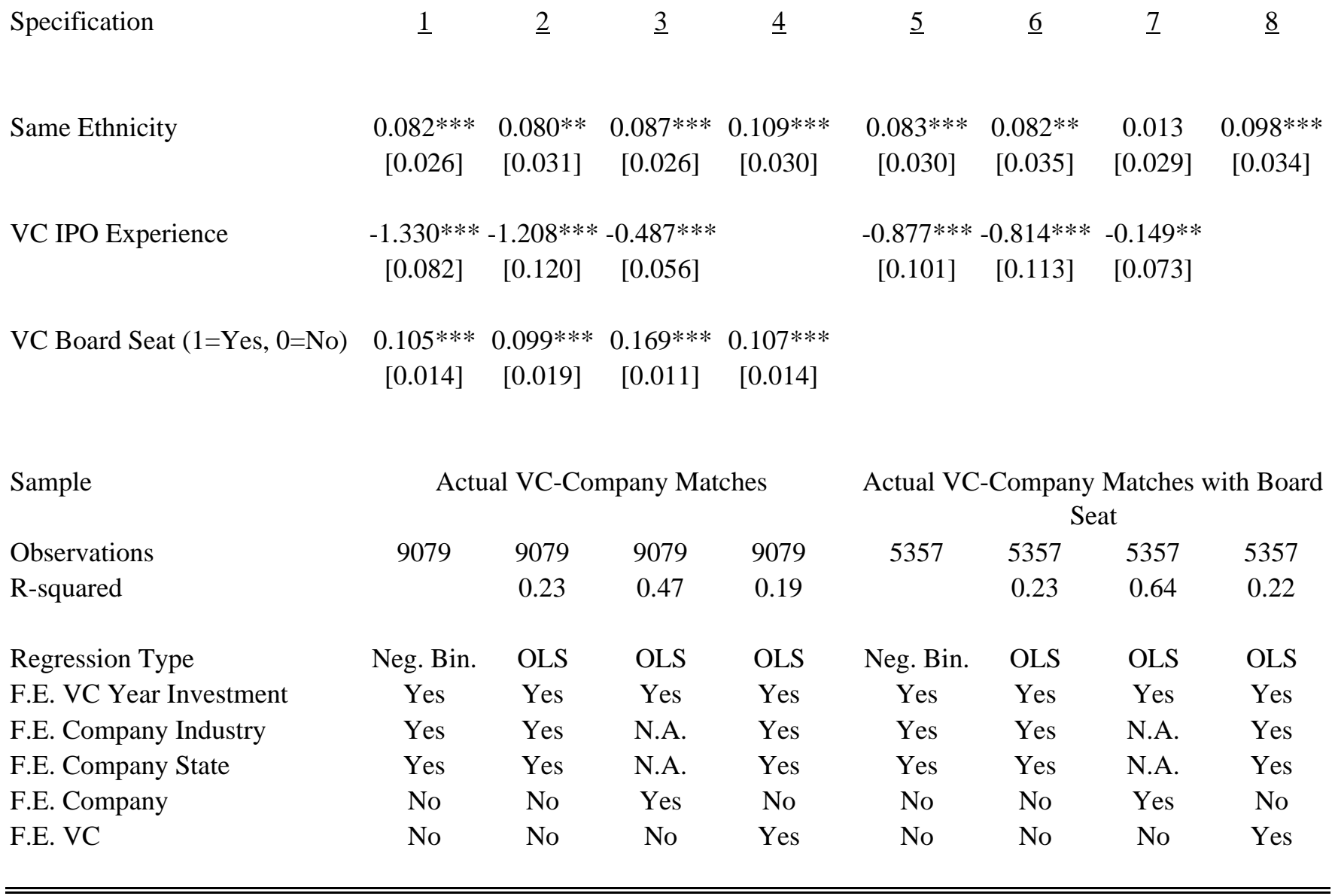




\section{Table 6 - continued}

Sample is actual VC-Company matches. In Panel B, the dependent variable is the logarithm of the total dollar amount VC invested in company. Specifications 1-3 include the full sample of actual VC-company matches, and specifications 4-6 includes only actual VC-company matches where the VC took a board seat. $V C$ IPO Experience is the historical fraction of the firm's portfolio companies that have had an IPO exit. Specifications 1 and 4 are OLS regressions with residuals clustered by both VC and company (Petersen, 2009). Specification 2 and 5 are fixed effect OLS with company fixed effects. Specifications 3 and 6 are fixed effect OLS with VC fixed effects. F.E. VC Year Investment are dummies for the year the VC first invested in the company. F.E. Company Industry are 10-segment VentureEconomics dummies. F.E. Company State are dummies for the U.S. of the company's headquarter. *** marks significance at $1 \%$, ** significance at $5 \%$,

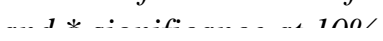

\section{Panel B: Dollar Amount}

Dependent Variable:

Specification

Same Ethnicity

VC IPO Experience

VC Board Seat $(1=$ Yes, $0=$ No)

$$
\begin{array}{ccc}
0.311^{* * *} & 0.357^{* * *} & 0.261^{* * *} \\
{[0.032]} & {[0.020]} & {[0.020]}
\end{array}
$$

Sample

Observations

R-squared

F.E. VC Year Investment

F.E. Company Industry

F.E. Company State

F.E. Company

F.E. VC
Actual VC-Company Matches

$9024 \quad 9024 \quad 9024$

0.11

0.14

0.11

Yes

Yes

Yes

No

No

Yes Yes

N.A. Yes

N.A. Yes

Yes No

No Yes

$\ln (1+$ Total Dollar Amount VC Invested in Company)

$\begin{array}{lllllll}\underline{1} & \underline{2} & \underline{3} & \underline{4} & \underline{5} & \underline{6}\end{array}$

$\begin{array}{cccccc}0.225^{* * *} & 0.091^{*} & 0.162 * * * & 0.191^{* * *} & 0.003 & 0.112^{* *} \\ {[0.047]} & {[0.050]} & {[0.044]} & {[0.053]} & {[0.058]} & {[0.047]} \\ & & & & & \\ 1.117^{* * *} & 0.617^{* * *} & & 1.539 * * * & 1.150^{* * *} & \\ {[0.206]} & {[0.107]} & & {[0.232]} & {[0.150]} & \end{array}$

Actual VC-Company Matches with Board Seat

$5319 \quad 5319$

5319

$0.14 \quad 0.18$

0.13

Yes Yes Yes

Yes N.A. Yes

Yes N.A. Yes

No Yes No

No No Yes




\section{Table 7 - Financial Contract}

Sample is actual VC-Company matches. In Panel A, the dependent variable is the logarithm of the premoney valuation of the company. The dependent variable is the average across all rounds in which VC invested in company (where data is available). Specifications 1-3 include the full sample of actual VCcompany matches, and specifications 4-6 includes only actual VC-company matches where the VC took a board seat. VC IPO Experience is the historical fraction of the firm's portfolio companies that have had an IPO exit. Specifications 1 and 4 are OLS regressions with residuals clustered by both VC and company (Petersen, 2009). Specification 2 and 5 are fixed effect OLS with company fixed effects. Specifications 3 and 6 are fixed effect OLS with VC fixed effects. F.E. VC Year Investment are dummies for the year the VC first invested in the company. F.E. Company Industry are 10-segment VentureEconomics dummies. F.E. Company State are dummies for the U.S. of the company's headquarter. ${ }^{* * *}$ marks significance at $1 \%$, ** significance at $5 \%$, and * significance at $10 \%$.

\section{Panel A: Pricing}

Dependent Variable:

Specification

Same Ethnicity

VC IPO Experience
In (1 + Pre-Money Valuation)

$12 \underline{3}$

$\underline{3}$

$\underline{4}$

$\underline{5}$

$\underline{6}$

$\begin{array}{lcccc}0.115 * & 0.011 & 0.107 & 0.204 * * * & -0.003 \\ {[0.068]} & {[0.033]} & {[0.073]} & {[0.076]} & {[0.041]} \\ & & & & \\ 1.874 * * * & 0.159 * * & & 1.782 * * * & 0.200 * \\ {[0.186]} & {[0.070]} & & {[0.271]} & {[0.112]}\end{array}$
[0.034]
[0.013]
$[0.033]$

Sample
Observations
R-squared
F.E. VC Year Investment
F.E. Company Industry
F.E. Company State
F.E. Company
F.E. VC

$$
\text { Actual VC-Company Matches }
$$

$4812 \quad 4812$

0.19

0.16

4812

0.14

Yes

Yes

Yes

No

No

$\begin{array}{cc}\text { Yes } & \text { Yes } \\ \text { N.A. } & \text { Yes } \\ \text { N.A. } & \text { Yes } \\ \text { Yes } & \text { No } \\ \text { No } & \text { Yes }\end{array}$

Actual VC-Company Matches with Board Seat

$\begin{array}{ccc}2499 & 2499 & 2499 \\ 0.15 & 0.2 & 0.13\end{array}$

$\begin{array}{ccc}\text { Yes } & \text { Yes } & \text { Yes } \\ \text { Yes } & \text { N.A. } & \text { Yes } \\ \text { Yes } & \text { N.A. } & \text { Yes } \\ \text { No } & \text { Yes } & \text { No } \\ \text { No } & \text { No } & \text { Yes }\end{array}$




\section{Table 7 - continued}

Sample is actual VC-Company matches. In Panel B, the dependent variable is the number of downside protection contingent cash flow rights (see Bengtsson and Sensoy, 2011, for details). A higher (lower) value of the index reflects a contract that is more (less) favorable to the VC and less (more) to the entrepreneur. The dependent variable is the average across all rounds in which VC invested in company (where data is available). Specifications 1-4 include the full sample of actual VC-company matches, and specifications 5-8 includes only actual VC-company matches where the VC took a board seat. VC IPO Experience is the historical fraction of the firm's portfolio companies that have had an IPO exit. Specifications 1 and 5 are negative binominal regressions with residuals clustered by company (we obtain similar results if we cluster by VC). Specifications 2 and 6 are OLS regressions with residuals clustered by both VC and company (Petersen, 2009). Specification 3 and 7 are fixed effect OLS with company fixed effects. Specifications 4 and 8 are fixed effect OLS with VC fixed effects. F.E. VC Year Investment are dummies for the year the VC first invested in the company. F.E. Company Industry are 10-segment VentureEconomics dummies. F.E. Company State are dummies for the U.S. of the company's headquarter. *** marks significance at $1 \%$, ** significance at $5 \%$, and * risnifinanno at $1 \mathrm{no}$

\section{Panel B: Contracting}

Dependent Variable:

Downside Protection Index (Bengtsson and Sensoy, 2011)

\begin{tabular}{|c|c|c|c|c|c|c|c|c|}
\hline Specification & $\underline{1}$ & $\underline{2}$ & $\underline{3}$ & $\underline{4}$ & $\underline{5}$ & $\underline{6}$ & $\underline{7}$ & $\underline{8}$ \\
\hline Same Ethnicity & $\begin{array}{l}-0.102 * * * \\
{[0.039]}\end{array}$ & $\begin{array}{c}-0.466 * * * \\
{[0.171]}\end{array}$ & $\begin{array}{c}0.006 \\
{[0.027]}\end{array}$ & $\begin{array}{c}-0.390 * * \\
{[0.172]}\end{array}$ & $\begin{array}{c}-0.128 * * * \\
{[0.041]}\end{array}$ & $\begin{array}{c}-0.584 * * * \\
{[0.173]}\end{array}$ & $\begin{array}{c}-0.025 \\
{[0.024]}\end{array}$ & $\begin{array}{l}-0.317 \\
{[0.195]}\end{array}$ \\
\hline VC IPO Experience & $\begin{array}{l}-0.387 * * * \\
{[0.088]}\end{array}$ & $\begin{array}{c}-1.825^{* * *} \\
{[0.440]}\end{array}$ & $\begin{array}{c}0.047 \\
{[0.065]}\end{array}$ & & $\begin{array}{c}-0.371^{* * *} \\
{[0.112]}\end{array}$ & $\begin{array}{c}-1.749 * * * \\
{[0.561]}\end{array}$ & $\begin{array}{l}0.169 * * \\
{[0.069]}\end{array}$ & \\
\hline VC Board Seat ( $1=$ Yes, $0=$ No) & $\begin{array}{l}0.016 \\
{[0.015]}\end{array}$ & $\begin{array}{c}0.076 \\
{[0.071]}\end{array}$ & $\begin{array}{l}0.022^{* *} \\
{[0.011]}\end{array}$ & $\begin{array}{c}0.125 \\
{[0.084]}\end{array}$ & & & & \\
\hline Sample & \multicolumn{4}{|c|}{ Actual VC-Company Matches } & \multicolumn{4}{|c|}{$\begin{array}{l}\text { Actual VC-Company Matches with Board } \\
\text { Seat }\end{array}$} \\
\hline Observations & 1923 & 1923 & 1923 & 1923 & 1289 & 1289 & 1289 & 1289 \\
\hline R-squared & & 0.17 & 0.01 & 0.1 & & 0.17 & 0.02 & 0.1 \\
\hline Regression Type & Neg. Bin. & OLS & OLS & OLS & Neg. Bin. & OLS & OLS & OLS \\
\hline F.E. VC Year Investment & Yes & Yes & Yes & Yes & Yes & Yes & Yes & Yes \\
\hline F.E. Company Industry & Yes & Yes & N.A. & Yes & Yes & Yes & N.A. & Yes \\
\hline F.E. Company State & Yes & Yes & N.A. & Yes & Yes & Yes & N.A. & Yes \\
\hline F.E. Company & No & No & Yes & No & No & No & Yes & No \\
\hline F.E. VC & No & No & No & Yes & No & No & No & Yes \\
\hline
\end{tabular}




\section{Table 8 - Company Exit}

Sample is actual VC-Company matches. OLS regressions. In Panel A, the dependent variable is 1 if the company had an IPO exit, and is 0 otherwise. In Panel B, the dependent variable is 1 if the company had an IPO or M\&A exit, and is 0 otherwise. In all specifications, the sample excludes investments after 2003 (our data is collected to 2009). Specifications 1-3 include the full sample of actual VC-company matches, and specifications 4-6 includes only actual VC-company matches where the VC took a board seat. VC IPO Experience is the historical fraction of the firm's portfolio companies that have had an IPO exit. Specifications 1, 2, 4 and 5 are OLS regressions with residuals clustered by both VC and company (Petersen, 2009). Specifications 3 and 6 are fixed effect OLS with VC fixed effects. Additional controls are company age at VC's first investment, whether VC invested in first round, number of rounds in which VC invested, dollar amount VC invested in company, and pre-money valuation. Specifications 2 and 5 also include distance company-VC as control and whether the company had any patents 5 years after the first VC round. F.E. VC Year Investment are dummies for the year the VC first invested in the company. F.E. Company Industry are 10-segment VentureEconomics dummies. F.E. Company State are dummies for the U.S. of the company's headquarter. ${ }^{* * *}$ marks significance at $1 \%$, ** significance at $5 \%$, and $*$ significance at 1 ก\%

\section{Panel A: IPO Exit}

Dependent Variable:

Company IPO Exit $(1=$ Yes, $0=$ No)

$\begin{array}{lcccccc}\text { Specification } & \underline{1} & \underline{2} & \underline{3} & \underline{4} & \underline{5} & \underline{6} \\ & & & & & & \\ \text { Same Ethnicity } & -0.051^{*} & -0.064^{* *} & -0.061^{* *} & -0.085^{* *} & -0.091^{* * *} & -0.070^{*} \\ & {[0.029]} & {[0.028]} & {[0.031]} & {[0.035]} & {[0.035]} & {[0.039]} \\ \text { VC IPO Experience } & 0.551^{* * *} & 0.575^{* * *} & & 0.557^{* * *} & 0.567^{* * *} & \\ & {[0.068]} & {[0.070]} & & {[0.081]} & {[0.084]} & \\ \text { VC Board Seat (1=Yes, 0=No) } & 0.022^{*} & 0.019 & 0.005 & & & \\ & {[0.012]} & {[0.013]} & {[0.014]} & & & \end{array}$

\begin{tabular}{lcccccc} 
Sample & \multicolumn{3}{l}{ Actual VC-Company Matches } & \multicolumn{3}{l}{ Actual VC-Company Matches with } \\
Observations & 3652 & 3569 & 3569 & 1802 & 1776 & 1776 \\
R-squared & 0.23 & 0.24 & 0.19 & 0.26 & 0.27 & 0.22 \\
F.E. VC Year Investment & Yes & Yes & Yes & Yes & Yes & Yes \\
F.E. Company Industry & Yes & Yes & Yes & Yes & Yes & Yes \\
F.E. Company State & Yes & Yes & Yes & Yes & Yes & Yes \\
Additional Controls & Yes & Yes & Yes & Yes & Yes & Yes \\
Distance and Patents & No & Yes & No & No & Yes & No \\
F.E. VC & No & No & Yes & No & No & Yes \\
& & & & & \\
\hline \hline
\end{tabular}


Table 8 - continued

Panel B: M\&A Exit

Dependent Variable:

Company IPO or M\&A Exit ( $1=$ Yes, $0=\mathrm{No}$ )

\begin{tabular}{|c|c|c|c|c|c|c|}
\hline Specification & $\underline{1}$ & $\underline{2}$ & $\underline{3}$ & $\underline{4}$ & $\underline{5}$ & $\underline{6}$ \\
\hline Same Ethnicity & $\begin{array}{c}-0.008 \\
{[0.038]}\end{array}$ & $\begin{array}{c}-0.025 \\
{[0.038]}\end{array}$ & $\begin{array}{l}-0.022 \\
{[0.038]}\end{array}$ & $\begin{array}{c}-0.084 * * \\
{[0.039]}\end{array}$ & $\begin{array}{c}-0.093 * * \\
{[0.039]}\end{array}$ & $\begin{array}{c}-0.107 * * \\
{[0.049]}\end{array}$ \\
\hline VC IPO Experience & $\begin{array}{c}0.238 * * * \\
{[0.083]}\end{array}$ & $\begin{array}{c}0.276 * * * \\
{[0.084]}\end{array}$ & & $\begin{array}{c}0.315^{* * *} \\
{[0.111]}\end{array}$ & $\begin{array}{c}0.327 * * * \\
{[0.112]}\end{array}$ & \\
\hline VC Board Seat $(1=$ Yes, $0=$ No) & $\begin{array}{l}0.032 * * \\
{[0.015]}\end{array}$ & $\begin{array}{l}0.029 * \\
{[0.015]}\end{array}$ & $\begin{array}{c}0.003 \\
{[0.018]}\end{array}$ & & & \\
\hline Sample & \multicolumn{3}{|c|}{ Actual VC-Company Matches } & \multicolumn{3}{|c|}{$\begin{array}{c}\text { Actual VC-Company Matches with } \\
\text { Board Seat }\end{array}$} \\
\hline Observations & 3652 & 3569 & 3569 & 1802 & 1776 & 1776 \\
\hline R-squared & 0.19 & 0.2 & 0.16 & 0.23 & 0.23 & 0.2 \\
\hline F.E. VC Year Investment & Yes & Yes & Yes & Yes & Yes & Yes \\
\hline F.E. Company Industry & Yes & Yes & Yes & Yes & Yes & Yes \\
\hline F.E. Company State & Yes & Yes & Yes & Yes & Yes & Yes \\
\hline Additional Controls & Yes & Yes & Yes & Yes & Yes & Yes \\
\hline Distance and Patents & No & Yes & No & No & Yes & No \\
\hline F.E. VC & No & No & Yes & No & No & Yes \\
\hline
\end{tabular}




\title{
Ethnic Matching in the U.S. Venture Capital Market
}

\author{
OLA BENGTSSON | DAVID H. HSU
}

We document that ethnicity is a major determinant of how founders of U.S. startup companies match with partners of U.S. VC firms. A shared ethnicity increases the likelihood that a VC firm invests in a startup, strengthens the degree of the VC firm's involvement, increases the size and scope of the investment, and makes the financial contract more entrepreneur-friendly. These findings are robust to specifications with VC firm or startup company fixed effects. Based on our finding that a shared ethnicity is associated with worse investment outcomes (IPO or M\&A), we infer that a VC partner may overestimate the benefits of investing in a founder from the same ethnic group. Our paper adds new evidence on the role of ethnic minorities in entrepreneurship, and contributes to prior studies of how VC firms overcome informational frictions.

Key Words: Entrepreneurship, Venture Capital, Matching, Ethnicity

JEL codes: G24, L26

\section{THE KNUT WICKSELL CENTRE FOR FINANCIAL STUDIES}

The Knut Wicksell Centre for Financial Studies conducts cutting-edge research in financial economics and related academic disciplines. Established in 2011, the Centre is a collaboration between Lund University School of Economics and Management and the Research Institute of Industrial Economics (IFN) in Stockholm. The Centre supports research projects, arranges seminars, and organizes conferences. A key goal of the Centre is to foster interaction between academics, practitioners and students to better understand current topics related to financial markets.

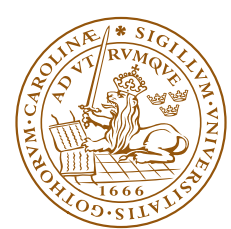

\section{LUND UNIVERSITY}

School of Economics and Management
LUND UNIVERSITY

SCHOOL OF ECONOMICS AND MANAGEMENT

Working paper 2013:8

The Knut Wicksell Centre for Financial Studies

Printed by Media-Tryck, Lund, Sweden 2013 